\title{
Land quality and soil organic carbon stocks consequent to land use change from natural forest to coffee plantation in a hot humid tropical ecosystem of Western Ghats, South India: Is it restorative enough?
}

Karthika K S ${ }^{1}$, K.S. Anil Kumar ${ }^{2}$, Nair K.M. ${ }^{3}$, Maria Violet D’Souza ${ }^{4}$, Nagaraj J.S. ${ }^{4}$, Lalitha $\mathrm{M}^{5}$, Arti Koyal ${ }^{3}$, Jayaramiah $\mathrm{M}^{1}$, Parvathy $\mathrm{S}^{3}$, shivanand khandal ${ }^{3}$, Sujatha $\mathrm{K}^{3}$, Ramamurthy $V^{1}$, S. Srinivas ${ }^{5}$, Raghuramulu Y. ${ }^{4}$, Rajendra hegde ${ }^{6}$, and SURENDRA $\mathrm{SINGH}^{7}$

${ }^{1}$ National Bureau of Soil Survey and Land Use Planning

${ }^{2}$ NBSS\&LUP(ICAR)

${ }^{3}$ ICAR-National Bureau of Soil Survey and Land Use Planning, Hebbal, Bangalore

${ }^{4}$ Coffee Research Institute, Chikmagalur, Karnataka

${ }^{5}$ ICAR-NBSSLUP

${ }^{6} \mathrm{NBSSLUP}$ (ICAR)

${ }^{7}$ NBSS\&LUP

May 5, 2020

\begin{abstract}
Western Ghats, known for its biodiversity, once well covered with dense forest, has been severely felled for cultivation of coffee, covering an area of 3.81 lakh ha and production of 3.27 lakh tonnes. To evaluate the effects of conversion from natural forests to coffee plantation on land quality, the changes in soil physical and chemical properties and soil organic carbon stock were assessed in selected hot per-humid, hot moist sub-humid and hot humid forest and coffee ecosystems of Chikmagalur district of Karnataka, Wayanad and Idukki districts of Kerala in the Western Ghats. Sixty sites were studied to understand the soil quality of which 46 sites were located in coffee plantations and 14 in forests adjacent to coffee plantations. In this study, six typifying pedons representing Chikmagalur district of Karnataka, Wayanad and Idukki districts of Kerala in the Western Ghats are explained by comparing the existing natural forest with that of coffee plantation ecosystem. The increase in soil organic carbon stocks (16.32-16.38 kg m-2 in forests to $14.32-19.28 \mathrm{~kg} \mathrm{~m}-2$ in coffee system), the most reliable indicator of land quality and other soil properties like clay content, $\mathrm{pH}$, exchangeable bases, CEC, available nutrients like $\mathrm{N}, \mathrm{P}, \mathrm{Ca}, \mathrm{Mg}, \mathrm{S}, \mathrm{Zn}$ and $\mathrm{Cu}$ in the study area revealed that there was an improvement in land quality, owing to lesser disturbance and better management in coffee plantation compared to forests on its conversion which indicates the restoration of land.
\end{abstract}

Keywords- coffee plantation, land use change, natural forest, soil carbon stock, land quality restoration

Introduction

Western Ghats, one of the world's ten "hottest biodiversity hotspots", was well covered with dense forest in the earlier days. Agro-ecosystems in the Western Ghats have depended on the forests for raw materials for food, fuel, fodder, fruits, timber, leaves, litter and various other products. Despite this, due to the expansion in area for agriculture, development of plantations and for other developmental activities, natural forests 
were cleared (Menon and Bawa, 1997; Jha et al., 2000). The burgeoning human population and decline in the per capita availability of land have resulted in increased exploitation of natural resources to a greater extent. The conversion of forest reserve to other land uses in recent times has resulted in many complex changes in the forest ecosystem, whose impact raises diverse ecological problems (Henrik et al., 2010; Awotoye et al., 2013). This destruction of natural forest from its niche as a result of its conversion has increased the need to assess the land use changes and their impact on land quality.

Global carbon cycle has gained paramount importance in the recent decades on account of alarming issues of climate change and global warming. Soil carbon is one of the components of global C cycle which plays a pivotal role in mitigating climate change by sequestering atmospheric carbon. Soil organic carbon pool is influenced by anthropogenic interventions, which could be by changes in land use or land cover (Khaledian et al., 2017; Hombegowda et al., 2016; Jaramillo et al., 2003). Changes in land cover and management practices result in changes in soil organic carbon stocks (Laganiere et al., 2010; Deng et al., 2013).

Land use changes such as forest clearing, cultivation and pasture introduction are also known to result in changes in soil chemical, physical and biological properties (Houghton et al., 1999), these changes vary with land cover and land management (Baskin and Binkley 1998; Celik, 2005). Soil physical and chemical properties are proposed as suitable indicators for assessing the effect of land use changes and management (Alvarez and Alvarez, 2000). Assessment of soil properties upon conversion of natural forests for varying agricultural purposes is of utmost importance to detect early changes in soil quality (Islam and Weil, 2000). Several studies have been reported on assessment of C stocks upon conversion of natural forests to agricultural ecosystems indicating a decline in $\mathrm{C}$ concentration by 20- 50 per cent (Lal, 2005; Lemenih and Itanna, 2004). However, several physiological attributes of coffee make it interesting to understand the differences in soil nutrient status on cultivation of coffee. Coffee is an exhaustive crop and gives away major part of photosynthates and nutrients through coffee beans even at the level that may cause exhaustion of the plant (Anil Kumar et al., 2014). Thus, it becomes important to know how cultivation of coffee has affected forest soils in terms of soil fertility and land quality.

To understand the impact of land use changes from forest to coffee plantations, efforts were made to study and characterize soils from these ecosystems. The objectives of this study were to assess the changes in physical and chemical properties of soils with emphasis on soil organic carbon stocks in response to the land use changes. The tropical soils of selected study sites are characterized by high temperature, high and intensive rainfall and permeable soils, which are vulnerable to sheet erosion.

\section{Study area}

The Western Ghats that run parallel to the west coast is endowed richly with different categories of forests. Coffee is an important plantation crop, mainly confined to the hills of South India, where Karnataka, Kerala and Tamil Nadu form the major traditional coffee growing regions with an area of 2.13, 0.84 and 0.31 lakh ha with a production of 2.52, 0.69 and 0.19 lakh tonnes respectively. The investigation included Chikmagalur district of Karnataka and Wayanad and Idukki districts of Kerala, located in the Western Ghats experiencing high rainfall and hot per-humid, hot moist sub-humid and hot humid tropical climates. Chikmagalur district lies in the north-eastern hills of Western Ghats and Balehonnur belonging to the Chikmagalur district receives an average annual rainfall of $2792 \mathrm{~mm}$, mainly from the south west monsoon during the months of June to September. Wayanad and Idukki districts of Kerala receive average annual rainfall of $2517 \mathrm{~mm}$ and 2305 $\mathrm{mm}$ respectively. Balehonnur, Wayanad and Idukki experience hot per-humid, hot moist sub-humid and hot humid tropical climate respectively and study area is depicted on a location map (Fig.1).

\section{Methods}

To evaluate the soil quality, a network of soil quality monitoring sites (SQMS) were established following the agro-climatic variability along the natural forest and traditional coffee growing areas in the Western Ghats. A total of 60 SQMS were excavated of which 46 sites were located in coffee plantations and 14 in forests adjacent to coffee plantations. In Chikmagalur a total of 9 profiles from coffee ecosystem and 4 profiles from natural forest ecosystem were studied. In Wayanad, 8 profiles under coffee plantation and 4 profiles from 
natural forest ecosystem, and in Idukki, 3 profiles each from coffee plantation and natural forest ecosystem were studied to understand the effects of conversion. From these identified study sites, six typifying pedons representing the area, three from natural forest ecosystem and three from coffee plantation ecosystem from the adjoining areas located in the Eastern (Malanad) hills, Nilgiri hills and Kumili hills of Western Ghats respectively, are described and characterized to meet the objectives of the study.

The details of the profiles for which analyses were carried out include:

Pedon 1 and 2 are located in the Chikmagalur district of Eastern hills of Western Ghats in which pedon 1 (Chikmagalur- Forest) was selected from a natural forest in Chikmagalur district of Karnataka adjacent to the CCRI campus. This steep sloping area (15-25 per cent) with slope length $300-600 \mathrm{~m}$ is located at an elevation of $805 \mathrm{~m}$ above MSL within latitude $13^{\circ} 21^{\prime} 35.1^{\prime \prime} \mathrm{N}$ and longitude 750 25' 28.0" E. Pedon 2 (Chikmagalur- Coffee ) was excavated from the CCRI coffee plantation located at the Balehonnur panchayat, Koppa taluk of Chikmagalur district. The coffee plantation is located within latitude 13o 21' 40.0 " $\mathrm{N}$ and longitude 75o 25' 38.5" E at an elevation of $827 \mathrm{~m}$ above MSL with a slope of 5-10 per cent with 150-300 m slope length. The geology is granite with weathered granite as the soil parent material.

Pedon 3 and Pedon 4 represents the Nilgiri hills of western Ghats where Pedon 3: (Wayanad- Forest) was excavated from an evergreen forest situated within latitude 11046 ' $17.5 " \mathrm{~N}$ and longitude $76 \mathrm{o} 07^{\prime} 43.2^{\prime \prime} \mathrm{E}$ in the Panamaram panchayat of Wayanad district of Kerala. The physiography is gently sloping highlands with 3-5 per cent slope and 150-300 m slope length. The geology is Archean granite gneiss and soil parent material is weathered granite gneiss. Pedon 4 (Wayanad- Coffee) belongs to the coffee plantation in the Vattakkara estate of Meenanagadi panchayat, S. Battery taluk in the Wayanad district of Kerala and it lies within latitude $11041^{\prime} 54.9 " \mathrm{~N}$ and longitude 760 11'33.6" E. The site has a slope of 5-10 per cent with 150-300 m length. The geology is granite and soil parent material is weathered granite.

Pedon 5 and 6 were excavated from the Kumili hills of Western Ghats in the Idukki district. Pedon 5: (Idukki Forest) is dug from a forest ecosystem belonging to the Udumbanchola Taluk of Shantanpara Panchayat in Idukki district of Kerala. The pedon lies within a latitude of 09 o 56 ' 13.1" N and longitude 77o 13' 43.2" E. The area has a slope of 5-10 per cent and slope length of 150-300 m. Pedon 6: (Idukki- Coffee) is from Gudanpara MNJ estate in the Shanthanpara panchayat of Idukki district of Kerala. The pedon lies within a latitude of 09056 o $42.5 " \mathrm{~N}$ and longitude $77 \mathrm{o}$ 13' 11.3 " E. The area has a slope of 3-5 per cent and slope length of 300-600 m. The geology is granite gneiss and formed the soil parent material after weathering.

Horizon-wise soil samples were analyzed using standard procedures for soil morphological, physical and chemical parameters. Soil bulk density was determined by the core method and mechanical composition of soils was determined following the International Pipette method. Cation exchange capacity (CEC) was determined by the ammonium acetate method (Jackson,1958). The ammonium acetate extract obtained from CEC estimation was used to determine the exchangeable bases by atomic absorption spectro-photometry and other soil chemical parameters were determined using standard analytical techniques (Jackson,1958).

Soil organic carbon was determined following dry combustion method using CHNS analyzer. Soil organic carbon stock for a given soil layer was calculated by multiplying the organic carbon concentration in soil fine earth with bulk density and soil depth using the following equation (Grossman, 2001).

$\mathrm{SOC}=(\mathrm{C} / 100) \mathrm{X} \rho \mathrm{X} \mathrm{D} \mathrm{X}(1-$ frag. $) \times 100$

where: $\mathrm{SOC}=$ soil organic carbon stock $\left(\mathrm{kg} \mathrm{m}^{-2}\right) ; \mathrm{C}=$ soil organic carbon concentration of soil fines (fraction $<2 \mathrm{~mm}$ ) determined in the laboratory $\left(\%, \mathrm{~g} \mathrm{~kg}^{-1}\right) ; \rho=$ soil bulk density $\left(\mathrm{g} \mathrm{cm}^{-3}\right) ; \mathrm{D}=$ depth of the sampled soil layer $(\mathrm{cm})$ and frag. $=\%$ volume of coarse fragments $/ 100$.

\section{Results}

\subsection{Selected morphological and physical properties of the soils}

Chikmagalur and Wayanad soils were very deep (depth $>150 \mathrm{~cm}$ ) and Idukki soils were deep (depth: 100$150 \mathrm{~cm})$ (Table 1). The soil colour of all the six pedons varied from dark brown to very dark brown in the 
surface and yellowish red to dark reddish brown in the lower horizons. Surface soils of the coffee plantations recorded higher clay content 29.33, 36.24 and 38.17 percent respectively in Chikmagalur, Wayanad and Idukki than the forest soils (Table 1). However, clay content was noticeably higher in Wayanad and Idukki coffee plantations with a decrease in sand content (Table 1). The bulk density of forest ecosystem soils ranged from 0.98 to $1.27 \mathrm{Mg} \mathrm{m}^{-1}$ at the surface whereas soils from coffee plantation ecosystem recorded bulk density from 1.15 to $1.36 \mathrm{Mg} \mathrm{m}^{-1}$ (Table 4).

\subsection{Soil reaction, exchangeable bases, extractable acidity, CEC and base saturation}

Surface soils of coffee plantation ecosystem recorded a pH of 6.10, 6.20 and 5.01 at Chikmagalur, Wayanad and Idukki respectively (Table 2). Coffee soils recorded relatively higher $\mathrm{pH}$ and exchangeable $\mathrm{Ca}$ and $\mathrm{Mg}$ than forest soils in all the profiles. Whereas, in Idukki, the soil reaction at the surface is not varying significantly between both systems (4.94 and 5.01) and only a slight decline in acidity in the coffee plantation ecosystem is observed. Total exchangeable bases of 3.42, 2.86 and $1.45 \mathrm{cmol}(+) \mathrm{kg}^{-1}$ of soil were recorded in coffee plantations and 2.41, 2.19 and $0.70 \mathrm{cmol}(+) \mathrm{kg}^{-1}$ of soil in forests of Chikmagalur, Wayanad and Idukki respectively. The coffee soils in its deeper layers recorded higher exchangeable Ca of 2.31, 1.70 and $1.08 \mathrm{cmol}(+) \mathrm{kg}^{-1}$ of soil in Chikmagalur, Wayanad and Idukki respectively (Table 2). $\mathrm{BaCl}_{2}$-TEA extractable acidity was higher in the forest soils and it was evident in the surface soils of Chikmagalur and Wayanad forest (20.20 and 12.20 respectively). Cation Exchange capacity (CEC) was noticeably higher in Chikmagalur and Idukki coffee plantations (98.06 and $30.12 \mathrm{cmol}(+) \mathrm{kg}^{-1}$ respectively) than forest soils.

\subsection{Available nutrients in soil}

Coffee soils in Wayanad and Idukki districts recorded higher $\mathrm{N}\left(282.2 \mathrm{~kg} \mathrm{ha}^{-1}\right.$ and $\left.407.7 \mathrm{~kg} \mathrm{ha}^{-1}\right)$ in the surface than forest soils however, the $\mathrm{N}$ content was higher in Chikmagalur forest soils $\left(407.7 \mathrm{~kg} \mathrm{ha}^{-1}\right)$ than coffee soils (Table 3 ). Coffee ecosystem soils recorded relatively higher P $\left(21.6,18.7\right.$ and $\left.16.1 \mathrm{~kg} \mathrm{ha}^{-1}\right)$ and lower potassium content $\left(284.5,206.1 \mathrm{and} 138.9 \mathrm{~kg} \mathrm{ha}^{-1}\right.$ respectively) in the surface soils of Chikmagalur, Wayanad and Idukki coffee plantations in comparison to that of forest soils. Coffee soils also recorded higher $\mathrm{Ca}\left(932.5,1125.0\right.$ and $530.5 \mathrm{mg} \mathrm{kg}{ }^{-1}$ of soil), $\mathrm{S}$ and micronutrients like $\mathrm{Zn}$ and $\mathrm{Cu}$ than forest soils. Calcium concentration at the deeper layers of forest soils $\left(245.2,209.5\right.$ and $77.5 \mathrm{mg} \mathrm{kg}^{-1}$ of soil) was relatively much lower than that of coffee soils. Magnesium content (73.5, 80.8 and $41.0 \mathrm{mg} \mathrm{kg}^{-1}$ of soil) also decreased with depth.

\subsection{Soil organic carbon content and SOC stock}

Soil organic carbon in the surface soil varied between 1.85 to 4.23 per cent (Table 4 ). The forest ecosystems recorded higher organic carbon content $4.23,2.53$ and 2.65 per cent at the surface soils of Chikmagalur, Wayanad and Idukki forests respectively. The reduction in the soil organic carbon content was prominent in the Wayanad coffee plantation in comparison with forest, the values varying from 2.53 to 1.85 per cent.

There was an increase in soil organic carbon stock on conversion from forest to coffee plantation in Wayanad and Idukki, whereas an observable reduction was recorded in Chikmagalur forest on conversion to coffee plantation where it reduced from 14.9 to $12.4 \mathrm{~kg} \mathrm{~m}^{-2}$ (Table 4). Soil organic carbon stock in the surface also recorded a noticeable reduction from $9.1 \mathrm{~kg} \mathrm{~m}^{-2}$ in the forest ecosystem to $7.3 \mathrm{~kg} \mathrm{~m}^{-2}$ in the coffee plantation.

\section{Discussion}

\subsection{Selected morphological and physical properties of soils}

The surface soils were darker in both the ecosystems which are a result of intensive decomposition of organic matter due to high temperature, intense leaching of bases due to high rainfall leaving sesqui-oxides at the surface and melanization or coating of dark colour over it and oxidative weathering in these humid tropics (Kharche et al., 2000). The increase in the clay content in the surface soils of coffee plantation in comparison to that of natural forest and the increase in clay content with depth up to the initial $100 \mathrm{~cm}$ in all the pedons is due to the dispersion of clay at the surface and illuviation of clay to lower layers (Kharche et al., 2000). The clay content further decreased and deeper layers recorded lesser clay content, which is due to 
the influence of parent material. Cultivated soils recorded higher clay content in the surface when compared to the forest ecosystem, owing to mixing of sub-surface soil layers rich in clay with surface, while making the land ready for starting of plantation. Bulk density of coffee plantation soils was comparatively more than that of forest ecosystem. However, these bulk density levels were in no way limiting for infiltration and movements of water (Nair et al., 2016). The lower bulk density at the surface is attributed to the influence of organic carbon rich surface soils, which is remaining intact in top layer with litter of forest trees, while in cultivated soils thickness of high organic carbon layer is more with little low organic carbon per cent due to mixing and intercultural operations (Nair et al., 2016).

The mean annual soil temperature was 22 ?C or higher classifying the soils in isohyperthermic temperature regime. The soils occur in the ustic soil moisture regime characterising it under ustic sub-group. In ustic soil moisture regime, when the soil temperature is $>22$ ? C, the soil moisture control section is dry in some or all parts for 90 or cumulative days in normal years. All the soils belong to order Ultisols and Humults sub order, which is assigned owing to very high levels of soil organic carbon in the top $50 \mathrm{~cm}(>0.9 \%)$. Humults are freely drained humus rich soils coming under order Ultisols.

Chikmagalur forest and coffee soils were very deep, moderately acid, dark brown in colour, low cation exchange capacity and base saturation and were classified as Kanhaplohumults and Kandihumults under Ustic subgroup respectively. Soils of Wayanad forest and coffee plantation were very deep, strongly acidic in sub-surface and slightly acidic in surface and were classified as Kandihumults and Haplohumults under Ustic sub-group respectively. Idukki soils were deep, strongly acidic with low cation exchange capacity and base saturation with dark brown in the surface to red or dark reddish brown colour in the deeper layers and were classified as Kandihumults and Palehumults under Ustic sub-group indicating the soil moisture control section is dry in some or all parts for 90 or cumulative days in normal years.

\subsection{Soil reaction, exchangeable bases, extractable acidity, CEC and base saturation}

The increase in $\mathrm{pH}$, exchangeable $\mathrm{Ca}$ and $\mathrm{Mg}$ in coffee soils has resulted from application of liming materials in the coffee plantation. In Chikmagalur, lime has gone down considerably, to $20 \mathrm{~cm}$, exhibiting the effect of dolomite application and the low Al concentration in Chikmagalur in comparison to Wayanad and Idukki. This increase in soil $\mathrm{pH}$ has resulted from a reduction in organic matter. Changes of soil $\mathrm{pH}$, a reduction of the litter habitat and increased anthropogenic disturbance via site management practices add to degradation (Nair et al., 2016). Liming of coffee plantation has corrected the strongly acidic soil reaction. Total exchangeable bases recorded higher in the deeper layers of coffee plantations in comparison to the forest system. The higher content of $\mathrm{Ca}$ and $\mathrm{Mg}$ in the deeper layers of coffee plantations is due to the leaching of $\mathrm{Ca}$ and $\mathrm{Mg}$ as a result of management of $\mathrm{Ca}$ and $\mathrm{Mg}$ in the coffee plantations of Chikmagalur and Wayanad. But in Idukki coffee plantation, there was no observable difference in $\mathrm{Ca}$ and $\mathrm{Mg}$ as well as in soil $\mathrm{pH}$, which has resulted from insignificant lime or dolomite application. $\mathrm{BaCl}_{2}$-TEA extractable acidity was higher in forest soils. This may be due to high organic carbon content and high intensity of leaching as a result of high rainfall (Kharche et al., 2000). Cation exchange capacity was more in coffee soils than forest soils. In all the profiles, CEC was higher in the surface soils due to the presence of higher organic matter and $\mathrm{Ca}$ and $\mathrm{Mg}$ in the surface layers. The CEC decreases on moving down the profile and lesser was the CEC recorded at deeper layers. This has resulted from the decomposition of organic matter. Calcite and dolomite applied to the coffee plantations leached down the profile and resulted in higher exchangeable $\mathrm{Ca}$ and $\mathrm{Mg}$ in the deeper layers. Soil CEC is important for maintaining soil fertility as it influences the total quantity of nutrients available to plants at the exchange site (Yitbarek et al., 2013). Soil CEC increased by following conversion of forest to crop fields (McGrath et al., 2001). The application of liming materials to neutralise the $\mathrm{pH}$ has served the purpose of soil conditioners which in direct contact with soils have evolved as a technique to achieve restoration of soil qualities upon conversion from natural forest to cultivated ecosystem (Saturday, 2018).

\subsection{Available nutrients in soil}

Nitrogen and potassium are the most important nutrients required by coffee. The higher $\mathrm{N}$ content in 
Chikmagalur forest $\left(407.7 \mathrm{~kg} \mathrm{ha}^{-1}\right)$ may be attributed to the higher organic carbon content $(4.23 \%)$ in the soil, when compared to Wayanad and Idukki forest soils. The higher concentration of $\mathrm{N}$ in coffee soils is a result of $\mathrm{N}$ fertilization. The phosphorus content decreased with depth and this trend was clear irrespective of forest or coffee plantation ecosystem. The higher $\mathrm{P}$ in the surface is attributed to the application of phosphatic fertilizers to coffee plantation and the effect of slightly higher $\mathrm{pH}$ of coffee soils. Coffee berries contain high concentration of potassium, which will be removed from field through harvesting. When forests are cleared for agricultural use, the efficient nutrient recycling mechanisms of the forests are disrupted and the nutrient availability in the topsoil is increased by fertilization thereby increasing the potential for nutrient leaching (Schroth et al., 1999). Coffee ecosystem soils recorded lesser K than forest soils, may be due to the greater uptake and removal of $\mathrm{K}$ by coffee. Continuous cultivation of coffee in the same site will lead to a depletion of soil K (Jessy, 2011). Application of acid forming inorganic fertilizers enhanced depletion of $\mathrm{K}^{+}$from the soil (Gebrelibanos and Mohammed, 2013). The relatively higher available Ca content in coffee soils $\left(932.5,1125.0\right.$ and $530.5 \mathrm{mg} \mathrm{kg}^{-1}$ of soil) is due to the application of liming materials to the plantation. The decrease in $\mathrm{Ca}$ and $\mathrm{Mg}$ contents with depth is attributed to leaching caused as a result of heavy rainfall in the areas considered for study. The lower concentration of $\mathrm{Ca}$ at the deeper layers of forest soils is due to root uptake of nutrients by the forest trees with roots extending beyond $1 \mathrm{~m}$ of depth. This uptake by plants might have removed the nutrient from the system. Coffee plantation ecosystem soils recorded higher available sulphur than that of forest ecosystem soils. This is attributed to the application of sulphur containing fertilizers. Coffee plantation ecosystem soils recorded higher $\mathrm{Zn}$ and $\mathrm{Cu}$ content in surface horizons than forest ecosystem soils. The relatively higher concentration of copper than forest ecosystem soils is a result of application of Bordeaux mixture to the plantation. High rainfall and high temperature in the granite gneiss landscape and laterization assisted the accumulation of sesqui-oxides under redoxi-morphic conditions favouring higher concentration of iron, aluminium, manganese and sometimes copper also.

The available nutrients viz. N, P, Ca, Mg, S, Zn and $\mathrm{Cu}$ were higher in coffee soils than forest soils indicating better quality of soils on conversion from natural forest to coffee plantation, an indication of better level of management as an enterprise with replenishing of nutrients with absorption or removal and better soil water conservation structures and with shade trees for canopy management help preventing vagaries of soil erosion.

\subsection{Soil organic carbon and soil organic carbon stock}

Soil organic carbon influences a wide range of physical, chemical and biological properties and is considered as the most important indicator of soil quality (Larson and Pierce, 1994). Soil organic carbon content was higher with thicker organic carbon rich surface soil layer in the forest ecosystems than coffee plantation ecosystems (Fig.2). The higher organic carbon content is attributed to the dense forest and surface cover of Western Ghats and deposition of plant litter. Several studies have arrived at similar results that soil organic carbon under plantation was lower than under adjacent (original) native forest (Turner and Lambert, 2000). There is more litter and root in forest and grassland soils than arable land and consequently the accumulation of soil organic carbon is more in forest and grassland soils (Zhang et al., 2012). The influence of conversion from natural vegetation to cultivable land on soil organic carbon content differs among regions. A decrease in soil organic carbon is observed as the impact of conversion from natural forest to coffee plantation (Afandi et al., 2002; Dariah et al., 2008). In mid sub-tropical mountainous areas, a reduction in soil organic carbon content on transition from native forest to arable land (Yang et al., 2009). Several factors like clay content and type, $\mathrm{pH}$, climate, hydrology, organic matter inputs determine the stabilization of carbon in soils. For a given climate, increased erosion and decreased organic matter input account for a decline in soil organic carbon (Anil Kumar et al., 2014).

Thus a reduction in the soil organic carbon content was resulted as the land use changed from natural forest to coffee plantation. The decomposition of organic matter under coffee plantation could occur more intensively as the land was relatively more open than forest. Soil disturbances involved in establishment of plantations resulting in changes in the rates of accumulation, turn over and decomposition of soil organic carbon, losses of carbon occurred at different rates in different parts of soil profile might have led to the 
decreased content of soil organic carbon in coffee plantation ecosystem. This result gives us a hint that plantation management systems need to be modified to reduce carbon losses.

Soil organic carbon stock in the surface also recorded a noticeable reduction from $9.1 \mathrm{~kg} \mathrm{~m}^{-2}$ in the forest ecosystem to $7.3 \mathrm{~kg} \mathrm{~m}^{-2}$ in the coffee plantation, indicating a lower contribution from leaf litter (Fig.3). Soil organic carbon stock was considered as an important index of soil fertility, traditionally, due to the nutrient supplying capacity and its positive effects on soil structure and soil biological properties. But as land use influences soil organic carbon stock, it provides a better indication on land quality considering $\mathrm{C}$ sequestration into the pedosphere. Thus soil organic carbon stock was assessed to understand the soil quality as it is one of the important indicators. Though there was a reduction in per cent soil organic carbon content in comparison to the natural forest soils, soil organic carbon stocks remained higher in the coffee plantations. The near zero tillage of coffee soils, complete canopy cover of the plantations and negligible soil erosion were primarily responsible for the higher organic carbon status in coffee soils (Nair et al., 2016). The soil organic carbon stock was consistent with that of SOC content over the $0-150 \mathrm{~cm}$ profile among all the pedons studied. Soil organic carbon storage was higher in forest profiles, which is related to the deep dense roots of forest trees whereas soil organic carbon stock was higher in coffee plantations in Wayanad and Idukki. The degraded nutrient status of soil could influence the soil carbon sequestration potential. The amplitude of change in SOC stock was higher at the surface than at the deeper layers in the profile. Soil organic carbon stock, most reliable indicator of land quality, provides an idea on the sustainability of land use. Thus it forms the basis to understand the restorative properties of coffee soils. From this study it was observed that the conversion of tropical forests into land for coffee plantation had positive impacts on soil properties and the soil carbon stock. Conversion of forest to coffee plantation caused an appreciable change in organic matter content resulting in increased concentration of soil carbon stock and exchangeable bases, hence a better land quality. Coffee, mainly grown as agro-forestry system, has also benefitted ecosystem services, in ecological restoration even after conversion from natural forest.

\section{Conclusion}

When the soils are converted from forest to coffee plantation, it has resulted in an increase in soil clay content, $\mathrm{pH}$, organic carbon stock, available nutrients and CEC in the coffee plantation ecosystem. The surface of coffee plantation soils recorded higher status of available nutrients indicating human interference by management practices as the conversion to plantation disrupts the efficient nutrient recycling mechanisms of the forests and increases the nutrient availability in the top soil by fertilization. The conversion has resulted in an increase in land quality and this could prove the restorative effects of conversion to coffee plantation.

However, forest ecosystems contain ecologically sensitive components. Though the land use change to plantation ecosystem has resulted in an improved nutrient status and land quality in terms of indicators like $\mathrm{pH}$, CEC, soil organic carbon stock, the ecologically sensitive components must have been disturbed as this could not be compensated by the effects of agricultural practices. Thus to improve soils under coffee plantation, organic matter input, proper soil conservation measures to reduce erosion could be considered sustainable. The practices that minimally disturb, replace or maintain the original structure of tropical forests tend to be those that are most likely to be sustainable in the long-term. On conversion of forest to coffee plantation, with change in land use, there was an overall increase in land quality reassured on par with forests, owing to good management of enterprise and canopy management involving shade trees.

\section{References}

Afandi, B., Rosadi, Maryanto, Nurarifani, M., Utomo, Senge, M. and Adachi, T. (2002). Sediment yield from various land use practices in a hilly tropical area of Lampung region, South Sumatra, Indonesia.J. Jpn. Soc. Soil Phys., 91: 25-38. https://jssoilphysics.com/downloads/pdf/091025.pdf Alvarez, R. \& Alvarez, C. R. (2000). Soil organic matter pools and their association with carbon mineralization kinetics. Soil Science Society of America Journal, 64: 184-189. doi:10.2136/sssaj2000.641184x Anil Kumar, K. S., Nair, K. M., Krishnan, P., Naidu, L. G. K. \& Sarkar, D. (2014). Cli- 
matic and terrain influence on acidity, exchangeable bases and cation exchange capacity in soils of coffee plantations of Karnataka. Journal of Plantation Crops, 42: 117-123. https://updatepublishing.com/journal/index.php/JPC/article/view/5569 Awotoye, O. O., Adebola, S. I. \& Matthew, O. J. (2013). The effects of land use changes on soil properties in a humid tropical location: Little-Ose forest reserve, South-western Nigeria. Research Journal of Agricultural and Environmental Management, 2: 176-182. http://www.apexjournal.org/RJAEM Baskin, M. and Binkley, D. (1998). Change in soil carbon following forestation in Hawaii. Ecology, 79: 828-833. DOI: 10.2307/176582 https://www.jstor.org/stable/176582 Celik, I. (2005). Land use effects on organic matter and physical properties of soil in a southern Mediterranean highland of Turkey.Soil and Tillage Research, 83: 270-277. https://doi.org/10.1016/j.still.2004.08.001 Dariah, A., Agus, F. \& Maswar (2008). Soil quality of the land under coffee based farming system (Case study at Sumberjaya, West Lampung).Indonesian soil and climate Journal, 1: 48-57. http://dx.doi.org/10.2017/jti.v0n23.2005.\%25p Deng, L., Shangguan, Z. P. \& Sweeney, S. (2013). Changes in soil carbon and nitrogen following land abandonment of farmland on the Loess Plateau, China. PLoS One. 8 (9) : p. e71923 https://doi.org/10.1371/annotation/61b7e0d56062-49b7-a270-c115dd3cb8f Gebrelibanos, T. \& Mohammed, A. (2013). Effects of land use/ cover changes on soil properties in a dry land watershed of Hirmi and its adjacent Agro Ecosystem: Northern Ethiopia. International Journal of Geosciences Research, 1: 45-57. Grossman, R. B., Harrms, D. S., Kingsbury, D. F., Shaw, R. K. \& Jenkins, A. B. (2001). Assessment of soil organic carbon using the US Soil Survey. In: Assessment methods for soil carbon. (Eds. R. Lal., J. Kimble, R. F. Follet and B. A. Stewart) CRC Press. Boca Raton., pp 87-102. Henrik, H., Gaetan, D., Brigitte, B. \& Christian, M. (2010). Negative or positive effects of plantation and intensive forestry on biodiversity: A matter of scale and perspective. Forestry Chronicles, 86: 354-364. https://doi.org/10.5558/tfc86354-3 Hombegowda, H.C., van Straaten, O., Köhler, M.\& Hölscher, D. (2016). On the rebound: soil organic carbon stocks can bounce back to near forest levels when agroforests replace agriculture in southern India. Soil Discuss, 2:13-23. https://ui.adsabs.harvard.edu/link_gateway/2015SOILD...2..871H/doi:10.5194/soild-2-871-2015 Houghton, R. A., Hacker, J. L. \& Lawrence, K. T. (1999). The US carbon budget: contributions from land use change. Science, 285: 574-578. 10.1126/science.285.5427.574 Islam, K. R. \& Weil, R. R. (2000). Land use effects on soil quality in a tropical forest ecosystem of Bangladesh. Agriculture Ecosystems Environment, 79: 9-16. https://doi.org/10.1016/S0167-8809(99)00145-0 Jackson, M. L. (1958). Soil Chemical Analysis, Prentice-Hall, New Jersey. Jaramillo, V.J., Kauffman, J. B., Renteía-Rodríguez, L., Cummings, D.L. \& Ellingson, L.J. (2003). Biomass, carbon nitrogen pools in Mexican tropical dry forest landscapes. Ecosystem, 6: 609-629. https://doi.org/10.1007/s10021-002-0195-4 Jessy, M. D. (2011). Potassium management in plantation crops with special reference to tea, coffee and rubber. Karnataka Journal Agricultural Sciences, 24: 67-74. Jha, C. S., Dutt, C. B. S. \& Bawa, K. S. (2000). Deforestation and land use changes in Western Ghats, India. Current Science,79: 231-238. https://www.jstor.org/stable/24103455 Khaledian, Y., Kiani, F., Ebrahimi, S., Brevik, E.C. \& Aitkenhead-Peterson, J. (2017). Assessment and monitoring of soil degradation during land use change using multivariate analysis. Land Degradation \& Development, 28: 128-141. https://doi.org/10.1002/ldr.2541 Kharche,V.K., Sehgal, J. \& Challa, O. (2000). Characterisation of coffee growing soils in Karnataka. Journal of the Indian Society of Soil Science 10: 59-66. https://www.researchgate.net/publication/301542112 Laganière, J., Angers, D.A. \& Paré, D. (2010). Carbon accumulation in agricultural soils after afforestation: a meta-analysis. Global Change Biology, 16: 439-453 https://doi.org/10.1111/j.13652486.2009.01930.x Lal, R. (2005). Forest soils and carbon sequestration. Forest Ecology and Management, 220: 242-258. https://doi.org/10.1016/j.foreco.2005.08.015 Larson, W. E. \& Pierce, F. J. (1994). The dynamics of soil quality as measure of sustainable management in defining soil quality for a sustainable environment. Soil Science Society of America Journal35: 37-51. https://dl.sciencesocieties.org/publications/books/abstracts/sssaspecialpubl/definingsoilqua/37?access=0\&view $=$ pdf 
Lemenih, M., \& Itanna, F. (2004). Soil carbon stocks and turnovers in various vegetation types and arable lands along elevation gradients in Southern Ethiopia. Geoderma, 123:177-188. https://doi.org/10.1016/j.geoderma.2004.02.004 McGrath, D. A., Smith, C. K., Gholz, H. L. \& Oliveira, F. D. (2001). Effects of Land-use change on soil nutrient dynamics in Amazonia.Ecosystem, 4: 625-645. https://doi.org/10.1007/s10021-001-0033-0 Menon, S. \& Bawa, K. S. (1997). Applications of geographic information systems, remote sensing and a landscape ecology approach to biodiversity conservation in Western Ghats. Current Science, 73: 134145. https://www.atree.org/sites/default/files/ja_1997_1_0.pdf Nair, K.M., Anil Kumar, K.S., Srinivas, S., Nagaraj, J.S., Violet D'Souza M., Raghuramulu,Y. Rajendra Hegde \& Singh, S.K. (2016). Soil Quality Monitoring sites (SQMS) for traditional coffee-growing areas of India. NBSS Publ.No. 1095. National Bureau of Soil Survey and Land Use Planning, Nagpur, India. Saturday, A. (2018). Restoration of degraded agricultural land: A review. Journal of Environmental and Health Scienceshttps://doi.org/10.15436/2378-6841.18.1928 Schroth, G., da Silva, L. F., Seixas, R., Teixeira, W. G., Jeferson, L. V. M. \& Zech, W., (1999). Sub soil accumulation of mineral nitrogen under polyculture and monoculture plantation, fallow and primary forest in a ferralitic Amazonian upland soil. Agriculture Ecosystem Environment, 75:109-120. https://doi.org/10.1016/S0167-8809(99)00068-7 Turner, J. \& Lambert, M., (2000). Change in organic carbon in forest plantation soils in Eastern Australia. Forest Ecology Management, 133: 231-247. https://doi.org/10.1016/S0378-1127(99)00236-4 Yang, Y., Xie, J., Sheng, H., Chen, G. , Li, Xu \&Yang, Z,. (2009). The impact of land use/cover change on soil organic carbon stocks and quality in mid-subtropical mountainous area of southern China. Journal of Geographical Sciences. 19. 49-57. 10.1007/s11442-009-0049-5. Yitbarek, T., Heluf, G., Kibebew, K., Shelem, B. (2013). Impacts of land use on selected physicochemical properties of soils of Abobo area, Western Ethiopia. Agriculture Forestry Fisheries, 2:177-180. doi: 10.11648/j.aff.20130205.11 Zhang, L., Xie, Z., Zhao, R. \& Wang, Y., (2012). The impact of land use change on soil organic carbon and labile organic carbon stocks in the Longzhong region of Loess Plateau. Journal of Arid Land,4: 241-250. doi: 10.3724/SP.J.1227.2012.00241

\section{Hosted file}

C stocks and restoration_Tables.docx available at https://authorea.com/users/299229/articles/ 428699-land-quality-and-soil-organic-carbon-stocks-consequent-to-land-use-change-fromnatural-forest-to-coffee-plantation-in-a-hot-humid-tropical-ecosystem-of-western-ghatssouth-india-is-it-restorative-enough 


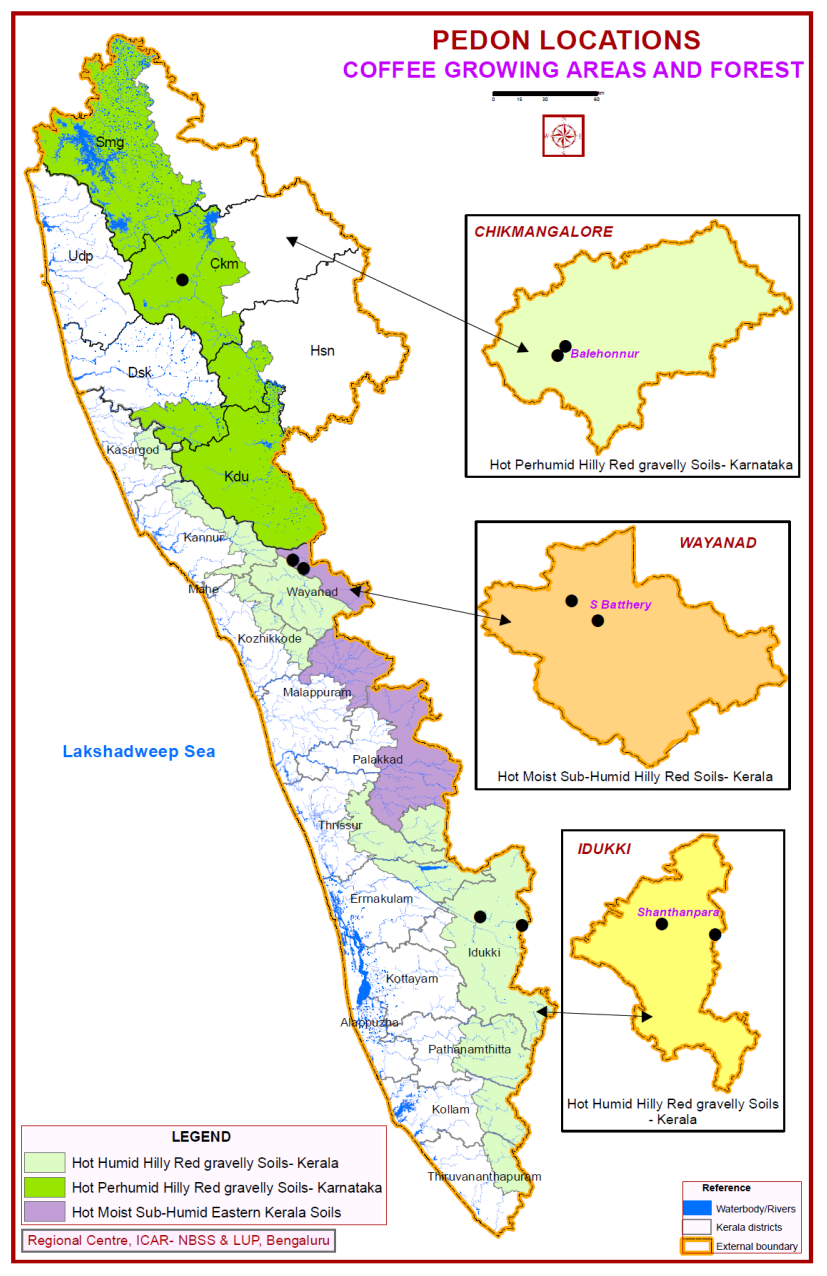

Fig.1 Location map showing study area and pedons 